\title{
Geomorphoclimatic characteristics and landform information in the Ejina Basin, Northwest China
}

\author{
Bingqi Zhu $\cdot$ Jingjie Yu $\cdot$ Patrick Rioual $\cdot$ \\ Yan Gao $\cdot$ Yichi Zhang $\cdot$ Leilei Min
}

Received: 9 April 2014/ Accepted: 25 November 2014/Published online: 6 December 2014

(C) Springer-Verlag Berlin Heidelberg 2014

\begin{abstract}
Natural environment of mid-latitude deserts of Central Asia is undergoing rapid changes. One of its elements is the relief. What needs to be particularly emphasized is its morphogenesis and landform evolution. In this study, a geomorphological research in the Ejina Basin (Inner Mongolia) is carried out with regard to identifying the main landforms and the contemporary geomorphic processes. We consider ancient and modern landforms as a unit and provide a general explanation for their evolution. Related environmental indications of existing landforms are discussed on the basis of climate geomorphology. Results show that the current basin is under the conditions favorable for the development and dominance of landforms originated from physical processes such as desiccationdeflation and aeolian. The landform system is characterized by its variable structure which is conditioned by specific hydrodynamics processes that existed during glaciations. It
\end{abstract}

Electronic supplementary material The online version of this article (doi:10.1007/s12665-014-3927-9) contains supplementary material, which is available to authorized users.

B. Zhu $(\bowtie) \cdot$ J. Yu $\cdot$ Y. Zhang $\cdot$ L. Min

Key Laboratory of Water Cycle and Related Land Surface

Processes, Institute of Geographic Sciences and Natural

Resources Research, Chinese Academy of Sciences,

Beijing 100101, China

e-mail: zhubingqi@igsnrr.ac.cn

P. Rioual

Key Laboratory of Cenozoic Geology and Environment, Institute of Geology and Geophysics, Chinese Academy of Sciences, Beijing 100029, China

Y. Gao

Centro de Investigaciones en Geografia Ambiental,

Universidad Nacional Autonoma de Mexico,

Campus Morelia, Mexico City, Mexico is suggested that landform patterns in Ejina are under the strong influence of rapid and/or intensive geomorphic processes. These signatures reflect the regional dynamics of landform evolution as characterized by a very effective integration of tectonic and climate-driven morphogenetic processes. Based on the present day climate data, we infer an obvious linkage of desert gorges and pediments in the basin to ancient humid phases, which provided high energy runoff for the formation of these landforms and were associated with erosional features under more humid and colder climate during the last glacial period. Desert plains and aeolian dunes in the central basin are the related products of contemporary climate. Clear evidences proving the landform inconsistency and landform instability in the Ejina are presented, indicating that the main geomorphic unit is experiencing transformation from alluvial plain to desert plain and then to aeolian dunes. However, the geomorphodiversity in the Ejina should be a compound result of complex surficial processes other than glaciation. Frost weathering, fluvial/alluvial action, desiccation-deflation and aeolian processes as well as climatic changes have played important roles.

Keywords Landform - Climate geomorphology · Geomorphogenic processes $\cdot$ Ejina $\cdot$ Central Asia

\section{Introduction}

Landform patterns in High and Central Asia provide evidence for the nature of the very dynamic landscape evolution through the late Cenozoic, including intense morphotectonic processes, high rates of denudation, sediment transfer and deposition (Kalvoda 2012a, b). Dominant relief processes and their development are the result of 
interactions between endogenic and exogenic processes. It has been suggested that the sensitivity/stability of the landscape in relation to climate (or the effectiveness of the links between the climate-related geomorphic processes), spatial environmental transitions and temporal environmental change are the three main driving forces determining the geomorphological significance of earth surficial interactions (Bullard and McTainsh 2003). In the mid-latitude arid zone of Central Asian, northern China experienced distinct variations in climate and hydrology during the late Quaternary resulting in variation in the form and size of desert landscapes (Yang and Scuderi 2010; Yang et al. 2011a, b).

In northern China, however, the evolution of inland desert landform differs from that in other areas of the world's inland deserts due to the interactions between modern climate and tectonic factors, and the influences of glaciations and large-scale sea level changes in the past (Derbyshire and Goudie 1997; Lehmkuhl and Haselein 2000; Sun 2002; Yang et al. 2011b, 2012; Stevens et al. 2013; Zhu et al. 2014a, b). Natural environments of midlatitude deserts in China are subject to relatively fast changes, one of the elements of which is the relief of the land (Yang et al. 2004). Morphology appears to be the most significant characteristic of relief, but it does not appear steady and is controlled by a set of interactive processes active over long periods. Previous studies, focused on inferring the responses of these geomorphic systems to past climatic change, have relied primarily on loess-paleosol profiles or stone-pavement development of out-desert deposits, which are indirect evidences in neighboring space. However, independent climatic controls on geomorphic features are difficult to establish in desert areas, due to the absence of long and continuous sedimentary sequences in situ (Yang 2001; Yang et al. 2004). Therefore, finding reliable proxy records of geomorphoclimatic effects in the deserts of the world remains a difficult issue.

The landscape conception in the sense of climatic geomorphology seems to be a promising method to answer this question (Garner 1959, 1967; Gutierrez 2005; Hoevermann 1985; King 1953; Nikiforov et al. 2005; Pekala 1975, 1980; Pekala and Zietara 1977, 1980; Peltier 1950; Pope et al. 1995; Stoddart 1969; Yang 2001). Geomorphologists postulate that climate must influence landforms and accordingly choose climatic boundaries which are anticipated to be significant for landforming processes (Gutierrez 2005; Hoevermann 1985; Pegui 1961; Peltier 1950; Wilson 1968; Yang 2001). They succeed into establishing some morphoclimatic systems and even into defining them in terms of temperature and precipitations. For example, based on consideration of two climatic parameters, i.e., mean annual temperature and total annual precipitation, Peltier (1950) established their relationship with five key geomorphic processes and distinguished two different morphogenetic elements. Tricart and Cailleux (1969) proposed a scheme which employed the major types of vegetation as indicators of morphoclimatic regions and its boundaries were chosen accordingly. Taking climate as a main dynamic contributor of landscape formation, Hoevermann (1985) established a corresponding relation between landforms and climate types in arid areas. Pope et al. (1995) proposed a conceptual model for understanding landscape evolution and geographical variations in weathering. In arid land, the morphogenic system of desert landscape has been treated within broader schemes of climatic geomorphology (Gutierrez 2005; Mabbutt 1977; Parsons and Abrahams 2009; Stoddart 1969). From the study of micro-landform development, valuable information for a better understanding of the climate events that has resulted in present-day landforms can be obtained (Gutierrez 2005).

The Ejina Basin, located the central part of the desert belt in northern China, is the western depression of the Alashan Plateau (Inner Mongolia) and is close to the north edge of the Tibetan Plateau. By its geographical location, the basin is on the northern fringe of the Asian summer monsoon and at the latitude of the westerlies (Fig. 1). Genesis of the Ejina Basin firstly demonstrates processes of erosion and accumulation of melterwaters derived from the Pacific and westerly moistures which occur on the background of changes in the height of erosion base and tectonic movements of the Tibetan Plateau. Geomorphological research in this area is thus significant for understanding the environmental effects of the upwelling of the Qinghai-Tibet Plateau and the variation of the East Asian monsoon (Guo et al. 2000). Until now, however, few studies were concerned with the landscape evolutions of the Ejina Basin. As a result of global climate warming, changes in relief morphology in the basin will be more active than at the present time. Natural processes determining landscape evolution should be regarded together with relief morphology. Special attention needs to be paid to the contemporary and ancient morphogenetic processes. In this study, we attempt to distinguish the dominant natural process that resulted in the landform formation and variation using precipitation and temperature data In the context of such an understanding, it is possible to ascertain future trends in relief morphology.

\section{Regional settings and methods}

The Ejina Basin belongs to the Mongolia Plateau glaciated in the Quaternary but presently non-glaciated areas of Central Asia (Grunert et al. 2000; Lehmkuhl and Haselein 2000). The basin is located between $40-43^{\circ} \mathrm{N}$ and $99-102^{\circ} \mathrm{E}$, west of the Alashan Plateau, Inner Mongolia in 

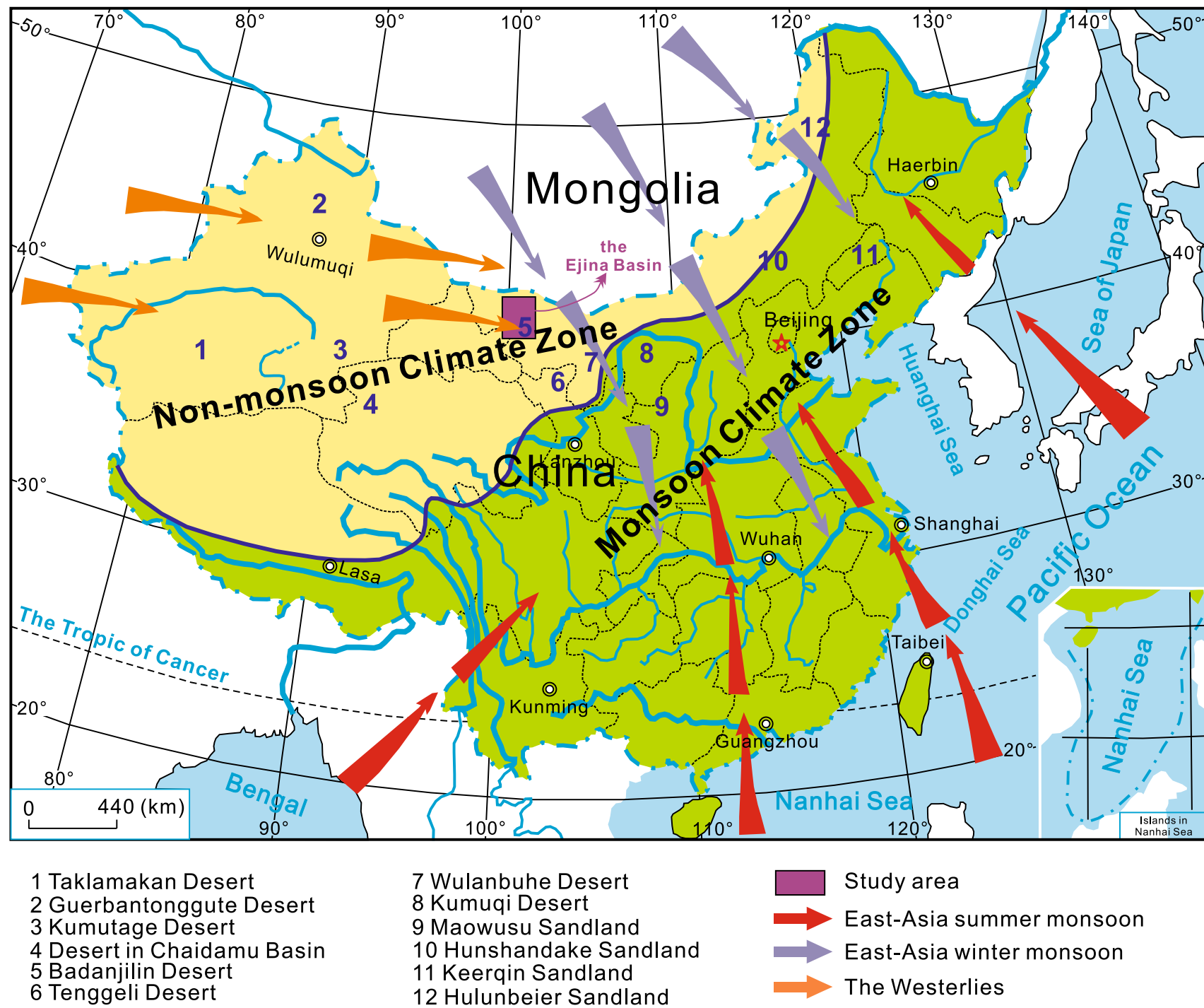

7 Wulanbuhe Desert

8 Kumuqi Desert

9 Maowusu Sandland

10 Hunshandake Sandland

11 Keerqin Sandland

12 Hulunbeier Sandland

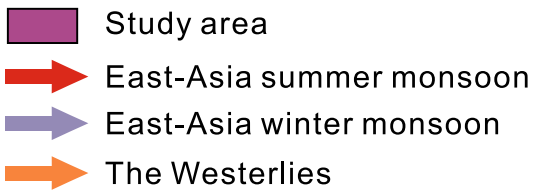

Fig. 1 Distribution of the sand deserts and sandy lands in China and the distribution of monsoon climate zone and non-monsoon climate zone (westerly zone + cold-arid regions in the Tibetan Plateau) (modified from Yang and Ding 2008; Zhu et al. 2012, 2014a)

China (Figs. 2, 3a). The drainage system is poorly developed on the Alashan Plateau, except in the Ejina Basin. The Ejina Basin is north-south trending in topography and is a regional tectonic depression limited to the east by the Badanjilin Desert units and to the west by the Mazong Mountains units (Fig. 2). Surface drainage in Ejina Basin is constituted by the Ejina (Ruoshui) River and its ephemeral tributaries, among which the most important are the East and the West rivers both coming from the Heihe River, one of the three largest inland river systems in China. The elevation of the basin declines from Langxinshan to Lake Sugunuoer by about $160 \mathrm{~m}$ along a distance of $160 \mathrm{~km}$ (Fig. 3b). Ejina Basin is one of the driest areas of the world, characterized by extremely continental temperate climate with hot summer and cold winter. The harshness of the present climate is manifested by wide annual temperature variations $\left(77^{\circ} \mathrm{C}\right)$, atmospheric transparency, low humidity, summer precipitation and very scarce pluvial precipitation. The mean annual temperature was $8.8^{\circ} \mathrm{C}$ at Ejina Basin over the last five decades (Fig. 3d), with a maximum daily temperature of $41{ }^{\circ} \mathrm{C}$ (July) and a minimum of $-36.4{ }^{\circ} \mathrm{C}$ (January). The rainfall regime is continental characterized by summer rains and very low average frequency of days with rain. The average annual precipitation in the last five decades is $35.6 \mathrm{~mm}$ (Fig. 3c). Prevailing winds come from the west (Fig. 3a), and northwest winds occur almost constantly during August-September.

The geological ground of the basin is made of unconsolidated sediments, sedimentary rocks (sandstone, siltstone, marly limestone, marl and dolomite) and underlying crystalline rocks which cracked tectonically into the system of Mongolian highlands and plateaus. This influenced 


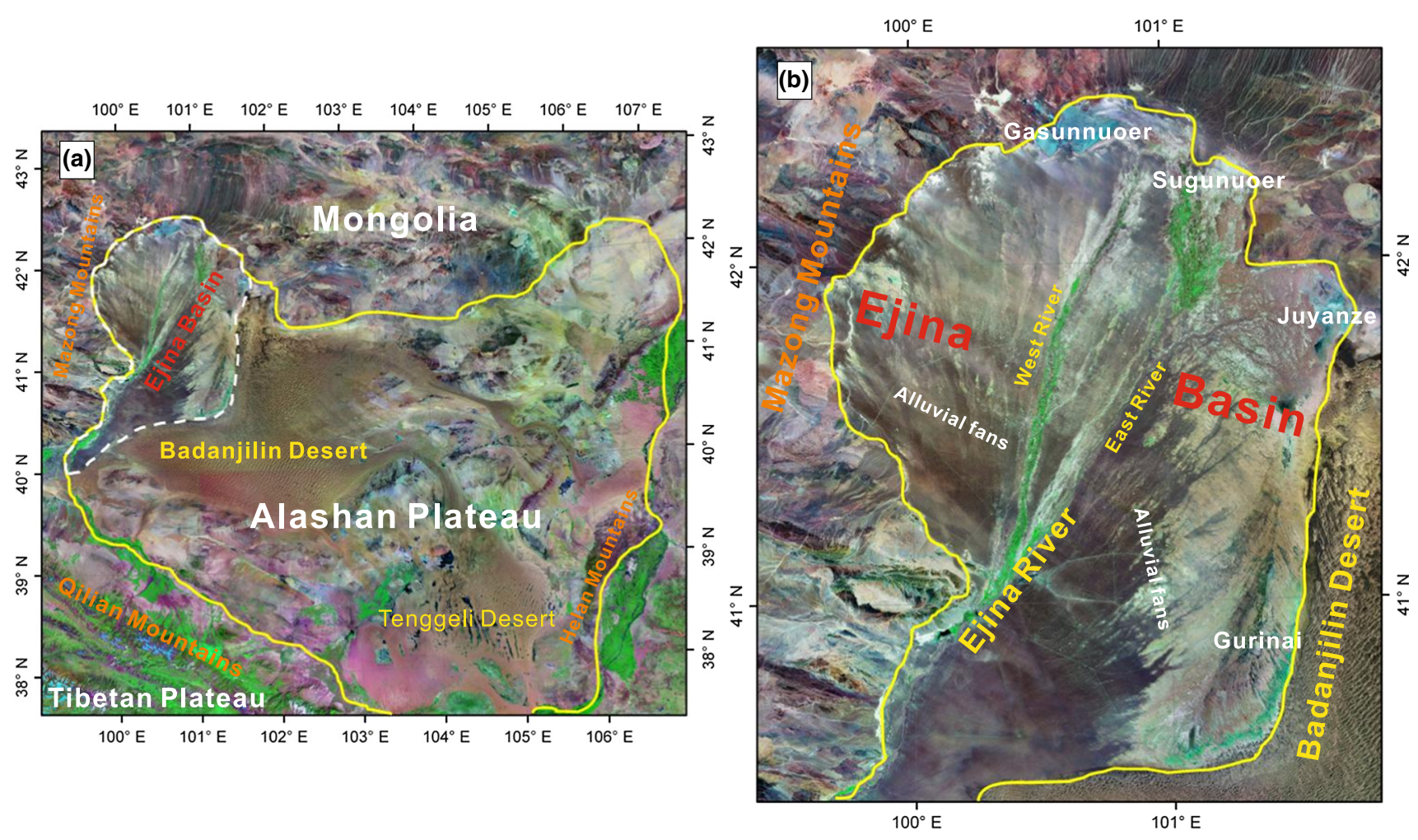

Fig. 2 Overview of the Alashan Plateau (a) and the Ejina Basin (b) by satellite images (Landsat TM, RGB 7-4-2, August 2000). Noting that large-scale alluvial fans are well preserved in the Ejina Basin

greatly the formation of the relief of the Ejina Basin as a result of long planation cycles in the Tertiary and Quaternary periods (Guo et al. 2000). Delta sediments that were connected with glacial/snow water accumulation are found in the outlet of the peripheral valleys in the basin ( $\mathrm{Lv}$ et al. 2010).

With respect to the landscape, the Ejina Basin belongs to a continental temperate region typified by the Eurasian steppes and deserts. Vegetation is poorly developed. Xerophytes are the main plant types which can survive desert conditions and are resistant to extreme temperatures and desiccation. In some places, vegetation is mainly represented by Artemisia-brine plant communities. Severe seasonal freezing affects the soils and outcrops in the basin. Large amounts of detritus are transported fluvially as gravel, silt and sand and deflated by strong winds during the winter and spring (Zhu et al. 2014c; Zhu and Yu 2014).

Field investigations of landforms were carried out in the whole Ejina Basin (Fig. 4). Inspection sites were selected based on the available aerial imagery and topographical maps. Since the presence of both erosional and depositional palaeosurfaces is a useful marker for reconstructing morphogenetic events (Robustelli et al. 2014), a detailed geological and geomorphological survey focused mainly on detecting these surfaces was performed, with the aim to characterize the Quaternary clastic sediment exposures and contact relationship. Landscapes in different scales and landscape features of different types were described based on the LANDSAT ETM + data, topographic maps and field examinations. Sedimentary facies and profiles were investigated to find out specific assemblages of genetically associated facies (facies association) to be used for interpretation of the depositional environment. To examine the selected elements of natural landforms at a detailed scale, available thematic maps at a scale of 1:500,000, topographical maps at the scale of 1:100,000, and aerial and satellite photographs were used. GPS and images from GoogleEarth at the scale of 1: 50,000 were also used for the orientation in the field. Observations and investigations on the contemporary morphogenetic processes in the zone of 2,500 $\mathrm{m}$ to $980 \mathrm{~m}$ a.s.l. were emphasized, with detailed investigation focused on the upper, middle and lower reaches of the Ejina River that flows from the Langxinshan northwards into the Lake Sugunuoer (East Juyanhai). Identification and classification of landscapes are mainly based on the system of climatic geomorphology, as shown in Table 1. Precipitation, temperature and wind records from AD 1960 to 2010 were collected from the Ejina Weather Station (affiliated to the Ejina Banner Bureau of Meteorology) located at the central part of the Ejina Basin and were used to interpret the potential geomorphoclimatic processes. 
(a)

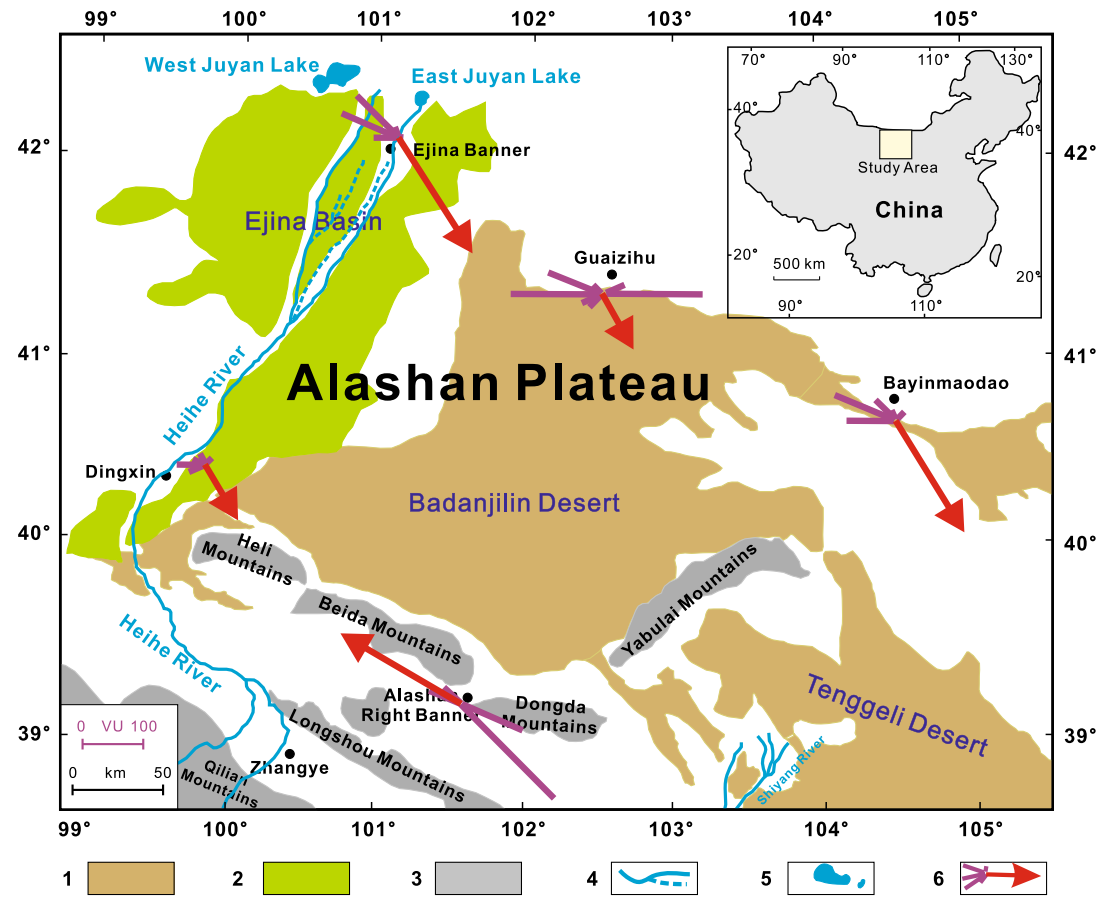

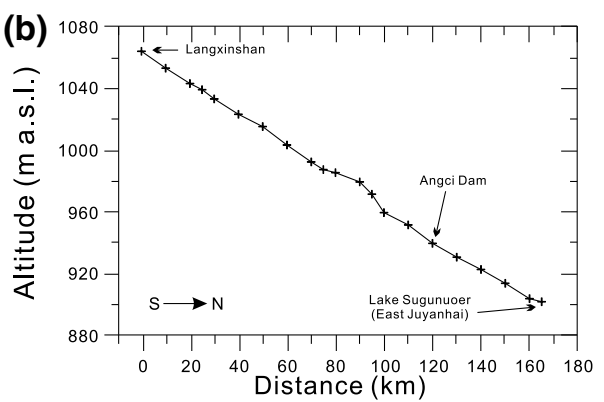

(c)
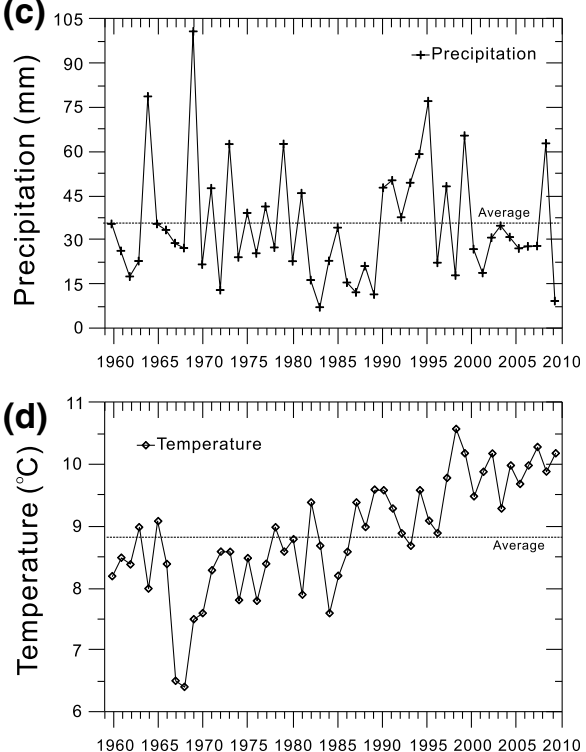

Fig. 3 a Landscapes of the Alashan Plateau (modified from Yang et al. 2011a), b a relief profile of the S-N trending line (along the East river from Langxinshan to Lake Sugunuoer), $\mathbf{c}$ the average annual precipitations, d temperatures (over 50 years during AD 1960-2010) in the Ejina Basin. The compound directions of wind systems in different areas in the Alashan Plateau are also shown in panel a. 1 sand dunes, 2 fluvial/alluvial sediments associated with the Heihe

\section{Results}

\section{Geomorphodiversity of the Ejina Basin}

The geomorphological complexity of the Ejina Basin is remarkable. It is a privileged place to observe the relationship between mountain, peneplain and basin playas which are directly connected to the genesis of the Ejina landscapes. As defined by Panizza (2009) and Testa et al. (2013), geomorphodiversity is a critical evaluation of the geomorphological characteristics and dynamics of a territory. The Ejina geomorphodiversity is firstly determined by lithology and tectonics factors, which are obvious morphotectodynamic processes indicated by significant gradients between mountain peaks (Mazong Mountains) and basin floors (Juyan Lake) in the Ejina.

Besides tectodynamics, satellite imagery and field observations also show that the most widely spread
River, 3 adjacent mountain ranges, 4 rivers, 5 lakes, and 6 sand roses (Fryberger and Dean 1979) for five surrounding weathering stations, with purple lines showing winds capable of transporting sand from various directions (DP, vector units with wind speed in knots VU) and red lines with arrows indicating the resultant sand transport trend (RDP, vector units in VU)

landscapes in the arid regions of China are desert plains and aerodynamic landforms (Hoevermann 1985; Yang 2001; Yang et al. 2004, 2011a, b), of which the Ejina Basin is the most representative. In the following, we provide detailed explanation about the types of the landforms in the Ejina Basin.

\section{Desert plain}

A large area of the Ejina Basin is typical of the characteristics of desert plain (Fig. 4f, Fig. S1). Desert plain can be divided into erosion type and accumulation type in terms of geomorphological process. Accumulation type, "Gobi" in the Chinese terminology, dominates at the central part of the Ejina Basin and also areas close to the aerodynamic relief. At the front zone to the surrounding highlands, erosion plains prevail (Fig. S1a). The sedimentary strata of desert plain in Ejina Basin are mainly 
Table 1 A concise state of major landscapes occurred in arid zones and their related climatic characteristics (Hoevermann 1985; Gutierrez 2005)

\begin{tabular}{|c|c|c|}
\hline Landscape division & Geomorphic feature & Climatic characteristics \\
\hline Glacial action zone & Glacier, glacial erosion and glacial deposition morphology & $\begin{array}{l}\text { Mean annual temperature of }-1 \text { to } \\
-13{ }^{\circ} \mathrm{C} \text { (varied with arid index) }\end{array}$ \\
\hline $\begin{array}{l}\text { Valley landscape } \\
\text { (a) Forest area } \\
\text { (b) Steppe zone }\end{array}$ & $\begin{array}{l}\text { Weak geomorphodynamic, soil formed, seasonal rivers, headward } \\
\text { erosion, humus layers development, ephemeral rivers, mild water } \\
\text { erosion, loess-like deposition, calcareous soil }\end{array}$ & $\begin{array}{l}\text { Annual mean temperature of } 1 \text { to }-5{ }^{\circ} \mathrm{C} \\
\text { the coldest month mean temperature of } \\
<-2{ }^{\circ} \mathrm{C}\end{array}$ \\
\hline Pediment & $\begin{array}{l}\text { Conical-shape deplanation and accumulation patterns, radial rill } \\
\text { networks }\end{array}$ & $\begin{array}{l}\text { Semi-arid (precipitation } 150-350 \mathrm{~mm} / \mathrm{a} \text { ), } \\
\text { strongly freeze-thaw weathering }\end{array}$ \\
\hline Desert gorges & Water-eroded patterns with steep wall-sides & Arid (precipitation 60-150 mm/a) \\
\hline Desert plain & $\begin{array}{l}\text { Gently inclined plains covered by sandy surface (formed jointly by wind } \\
\text { and water) }\end{array}$ & Arid (precipitation 30-50 mm/a) \\
\hline $\begin{array}{c}\text { Aerodynamic } \\
\text { topography }\end{array}$ & $\begin{array}{l}\text { Dunes, wind-eroded deflation depressions and Yardangs (aeolian } \\
\text { patterns) }\end{array}$ & Arid (precipitation <30 mm/a) \\
\hline
\end{tabular}

proluvial-alluvial deposits (Fig. 4g, Fig. S2a). There are also complicated sequences with sand, gravel, silt and clay sediments that involved alluvial, fluvial, lacustrine and aeolian processes (Fig. S2b), and thick clayey deposits formed by lacustrine processes (Fig. S2c). Slightly eroded shallow sections by fluvial processes are often observed in desert plains (Fig. S2d) and huge lacustrine profiles occur in the lower northern part of the desert plain (Fig. 4c, Fig. S2e). The upper sediments in areas of Gobi desert are composed of sand, silt and gravel and gravels lie mostly in a relatively thin layer above the surface, known as desert pavements (Fig. S1b, d).

\section{Pediments and desert gorges}

Around the western and northern edges of the Ejina Basin, pediments appear on the foot zone of mountains and in the higher sections of desert plains (Fig. 4e, h, Fig. S3a-b). This type of landform represents a conical relief characterized by a channel net. Desert gorges are widely distributed in the surrounding mountain slopes like the Mazong Mountains (Fig. S3c, d). Storeys of desert gorge occur in the upper part of the pediments and the desert plains. They usually dissect the mountain fronts. The landscape of desert gorges was produced by water and there is evidence of former severe erosion (Fig. S3c). In some places, loose sand layer tends to cover the gorge surface by aeolian and desiccation-deflation processes, due to the lack of water (Fig. 4d, Fig. S3d).

\section{Aerodynamic landform}

It refers to aeolian dune fields of various forms and deflation depressions. Dune fields in the Ejina Basin are mainly located along the two banksides of the Ejina River (Fig. S4a-c) and are surrounded by Gobi plains (Fig. S4c, S5). Regarding fixation degree by vegetation covered on them, the dunes can be divided into three main types: active (Fig. S4d), semi-active (Fig. S4e) and fixed dune (Fig. S4f). On the dune surface, vegetation types such as Populus euphratica, Tamarix chinensis, Artemisia spp, Agriophyllum arenarium, etc. are scarcely distributed (Fig. S4a-c).

\section{Alluvial and fluvial landforms}

The alluvial and fluvial landforms in the Ejina Basin are characterized by low-gradient courses and small slopes with flat and wide terrain (Fig. S6a, b) of a modal angle less than $0.1^{\circ}\left(0.06^{\circ}\right)$ (Fig. 3b). The fluvial landforms occur only in the Ejina Basin throughout the Alashan Plateau (Fig. 3a). The Ejina River follows a S-N direction spanning about $160 \mathrm{~km}$ from the south corner of the basin (Langxinshan) to the Lake East Juyanhai (Fig. 2b), where a relatively large ancient delta and alluvial fan had formed. The stem river channel is about $500 \mathrm{~m}$ to $1 \mathrm{~km}$ wide (Fig. 4;Fig. S6a, b) and the river beds are composed of sandy sediments (Fig. S6c). Water supply consists of markedly intermittent flood discharges with muddy water (Fig. S6d) during the spring and rainy seasons. In recent years, the duration of floods has been shortened due to the water conservancy programs of the Heihe catchment. By contrast, sediment yields are considerable, especially in the Quaternary history. Many palaeo-river channels can still be identified both from the investigations in the field and from historical maps and satellite images (Fig. 2b).

\section{Playas}

In the low terrains and distal areas of the alluvial fans in the Ejina Basin (mainly the northern part), modern and ancient lakebeds are widely distributed (Fig. S7a-d). There are also extensive areas with lacustrine and paludal sediments distributed in the east, central and northern peripheries of the 

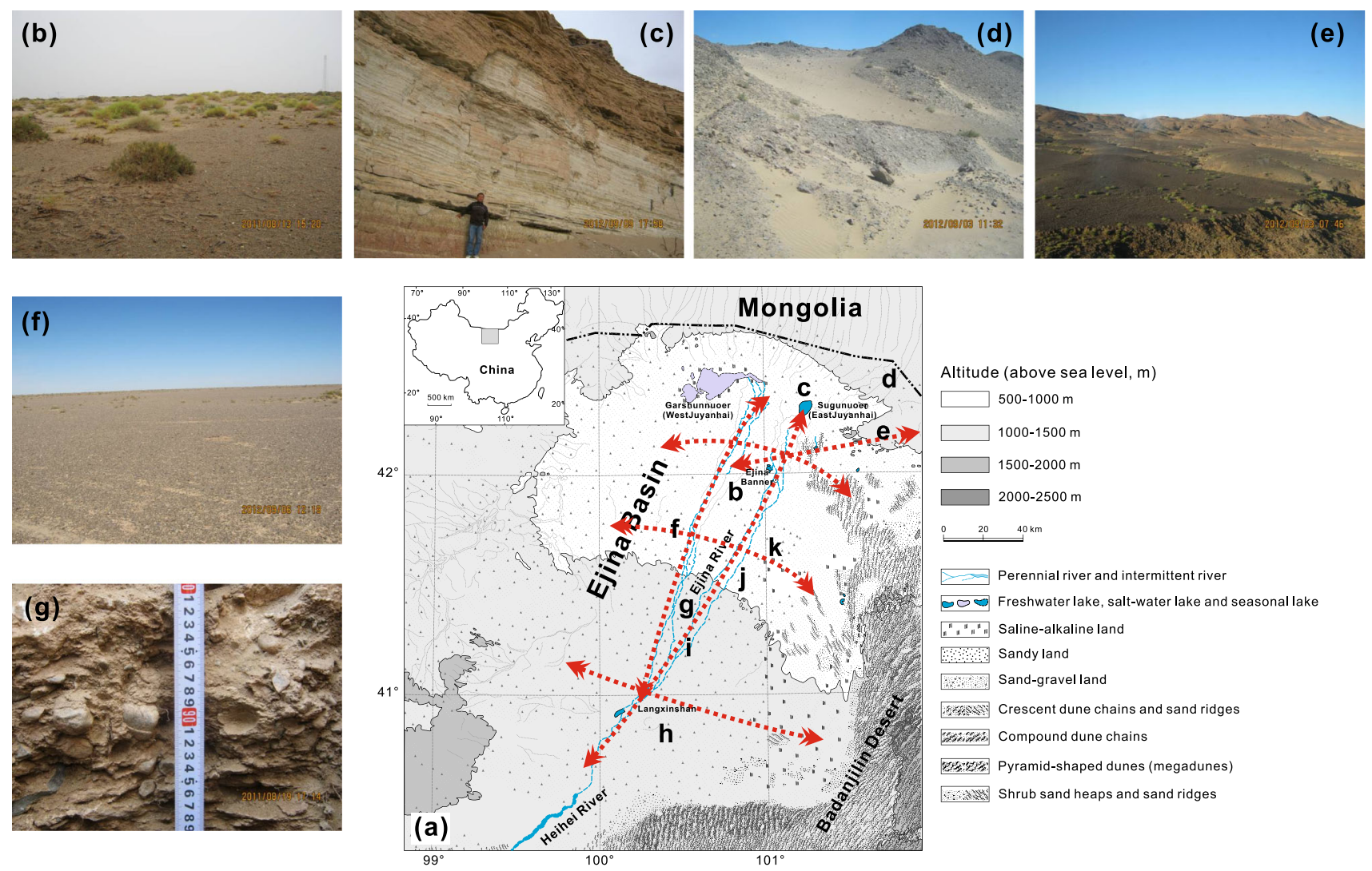

Altitude (above sea level, $\mathrm{m}$ )
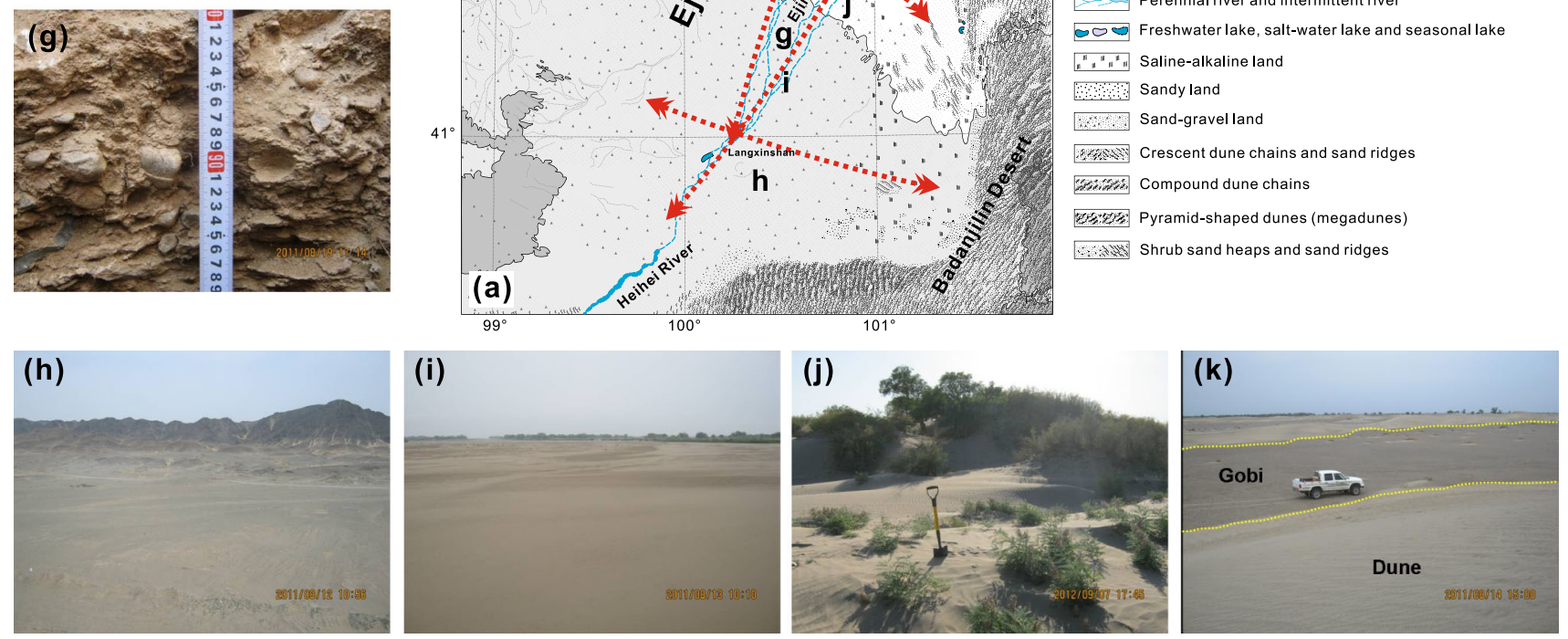

Fig. 4 The topographical map of the Ejina Basin a and some of the field photographs of the typical landforms observed in the basin (bk). The field investigation routes are also shown in figure a with red arrows and dot lines. b Steppe desert, c outcrop of palaeo-lacustrine sedimentation, d desert gorge, e pediment, f desert plain (Gobi

desert), $\mathbf{g}$ typical sedimentation under ground surface of desert plains in the central part of the basin, $\mathbf{h}$ pediment, $\mathbf{i}$ riverbed surface of the Ejina River (the East River, about $500 \mathrm{~m}$ in width), $\mathbf{j}$ dune field near river bank, $\mathbf{k}$ dune field on Gobi desert

Ejina Basin. The Gurinai Lake basin extends $120 \mathrm{~km}$ from south to north and about $50 \mathrm{~km}$ from east to west. The Garshunnuoer (Fig. S7b) and Sugunuoer lakes (Fig. S7c) are about $100 \mathrm{~km}$ long in the east-west direction and up to $40 \mathrm{~km}$ wide from south to north. The dimension of the Guaizihu Lake and Juyanze basins is about $60 \times 60 \mathrm{~km}$. These ancient lake basins have now thoroughly dried up. Playas in the basin are evidence of higher past lake levels or even the existence of a palaeolake, covering an area of about $15,000 \mathrm{~km}^{2}$. From the examination of remote-sensing images, it would appear that these were apparently the terminal lakes of the Ejina River (Fig. S7). Fluvial sediments interlay with lacustrine deposits in all profiles (Fig. S2b). Whiter-color clayey sediment strata (Fig. S2e) still

exist in some areas of the former lakebeds. In the central part of the Ejina Basin along the course of the Ejina River, there are thick layers of lake sediments that were deposited in previous periods with strong hydrological conditions (Fig. S2c).

Contemporary morphoclimatic processes in the Ejina Basin

An alternative approach postulates the range of selected climatic parameters in determining the relative importance of the main geomorphic processes, as defined in the morphogenic regions. Peltier (1950) used mean annual temperature and rainfall to define zones of intensity of 
frost action and chemical weathering, and hence weathering regions, and similarly for mass movement, wind action and pluvial erosion, as shown in Fig. 5. The Peltier diagrams illustrate: (1) the affiliation to the morphoclimatic regions; (2) the intensity of mechanical weathering and of chemical alteration; (3) the intensity of fluvial action (Fig. 5). The classifications for the morphogenetic regions based on climate are defined as: (1) selva, (2) maritime, (3) moderate, (4) savanna, (5) semi-arid, (6) arid, (7) boreal, (8) periglacial, (9) glacial (Fig. 6a). The
Fig. 5 Effectiveness of landforming processes under different climatic conditions, related to arid and semiarid morphogenic regions. The basegraphs were after Peltier (1950)

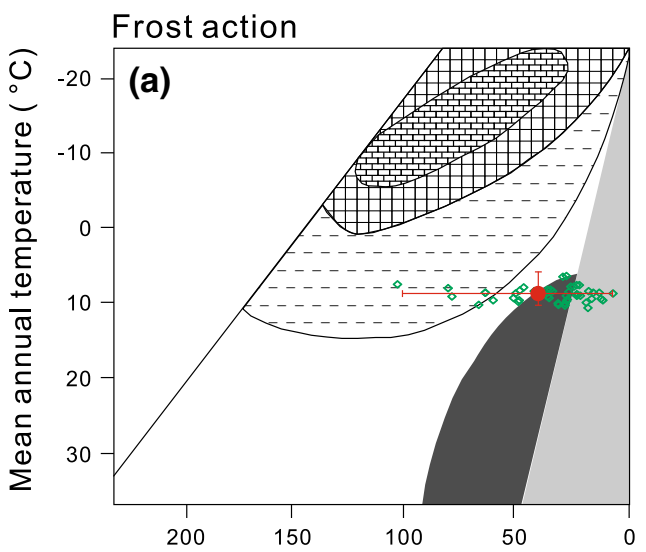

\section{Chemical Weathering}
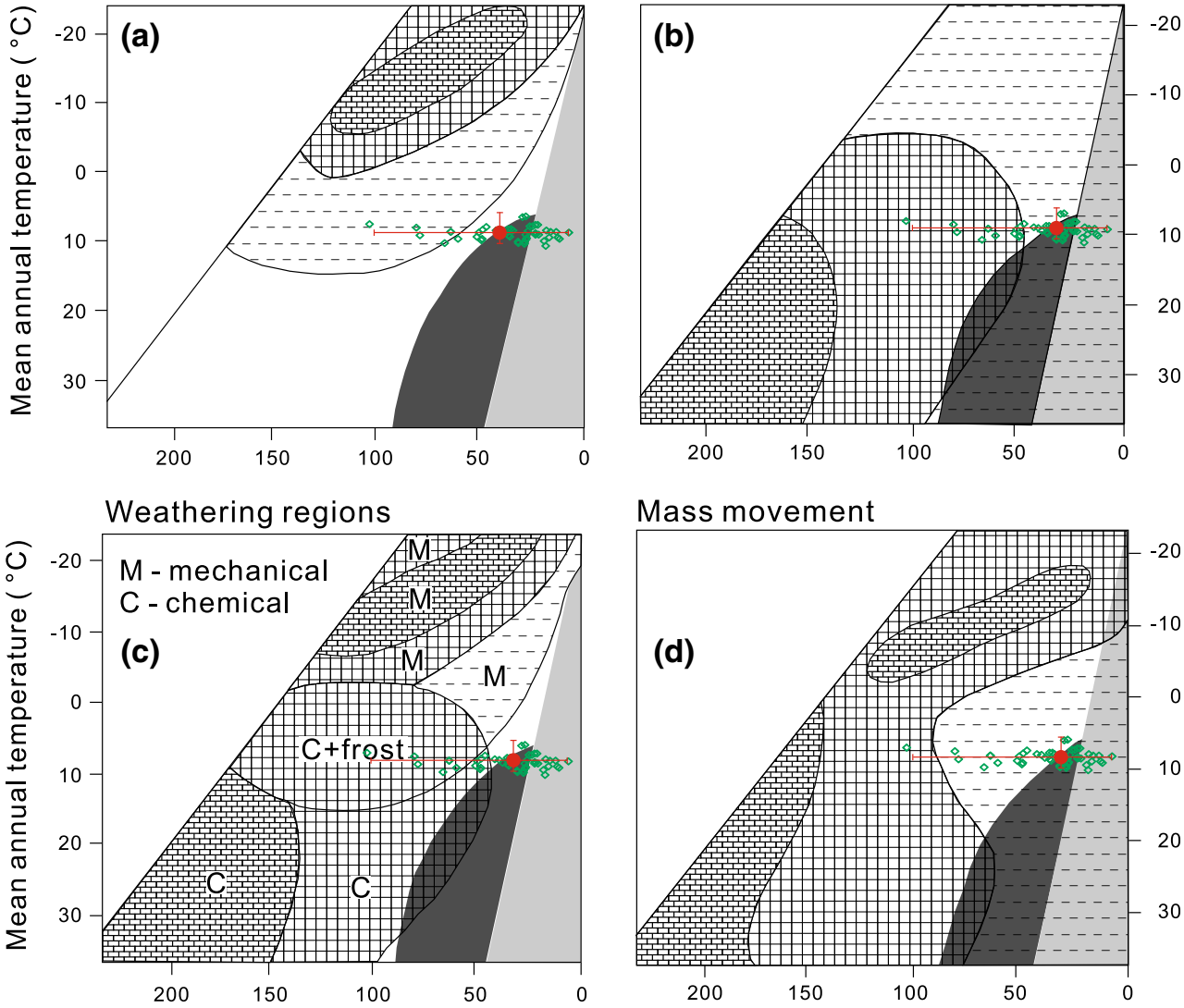

\section{Mass movement}

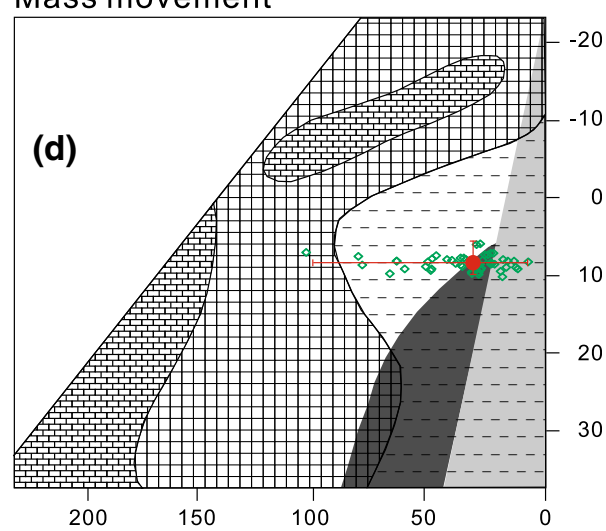

Pluvial Erosion
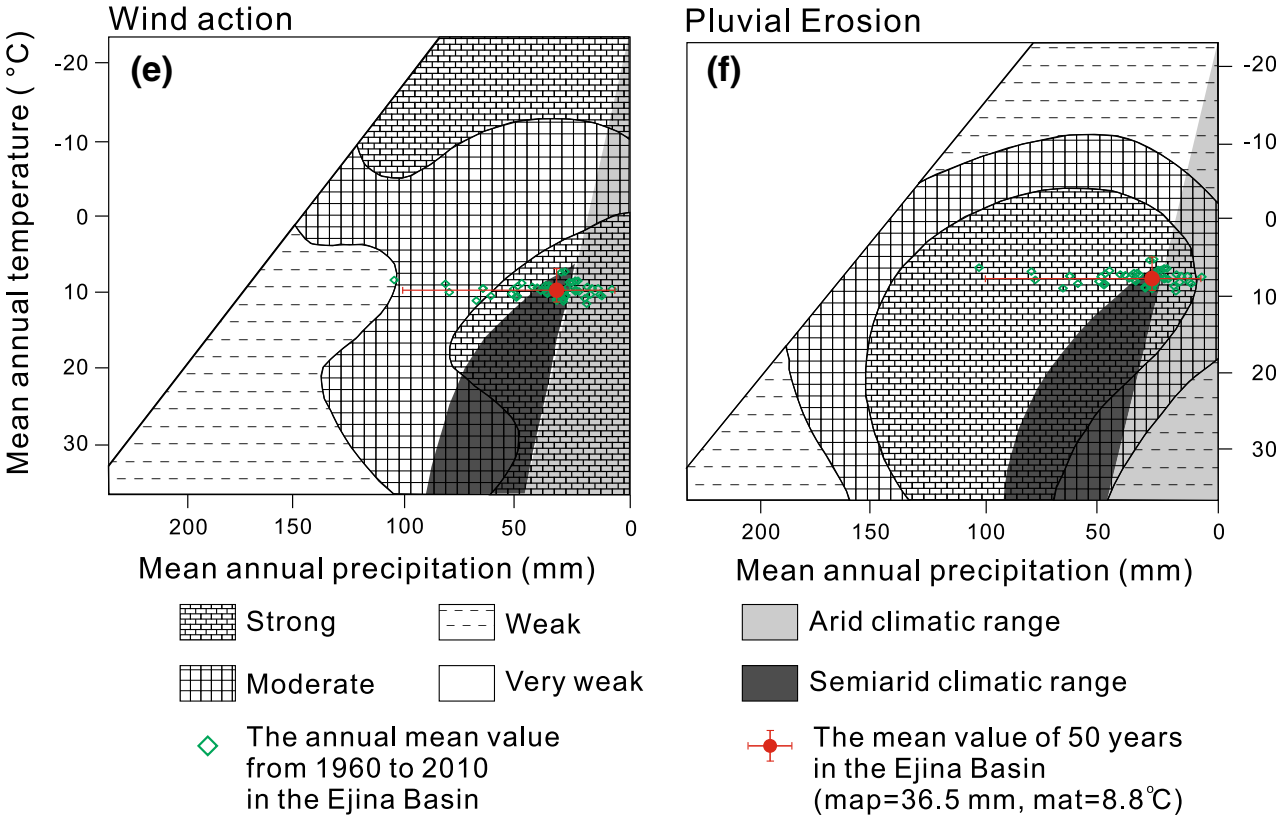
range of arid (warm arid) and semiarid morphogenic regions superposed on the Peltier diagrams has been proved by researchers to show the relative effectiveness of the various processes, such as Mabbutt (1977) and Gutierrez (2005).

Applied to the meteorological data from the Ejina Basin, such as the yearly temperature and precipitation values in the past five decades, the Peltier's diagrams point out to the following:

1. The morphoclimatic systems to which the Ejina Basin is affiliated are the semiarid (low amounts of precipitation and warm to hot) and arid systems (very little precipitation and hot) for which physical processes dominate (Figs. 5, 6).

(a)

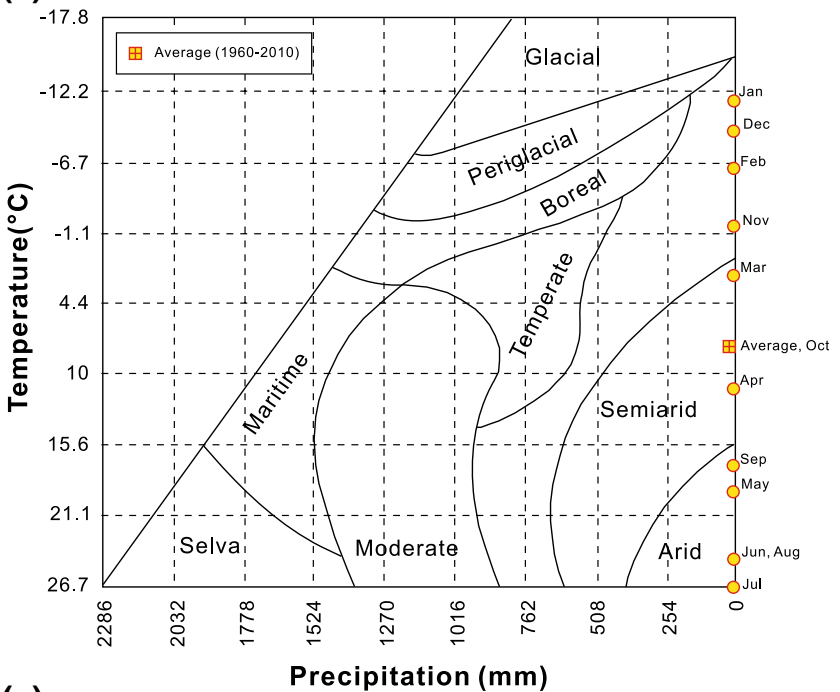

(c)

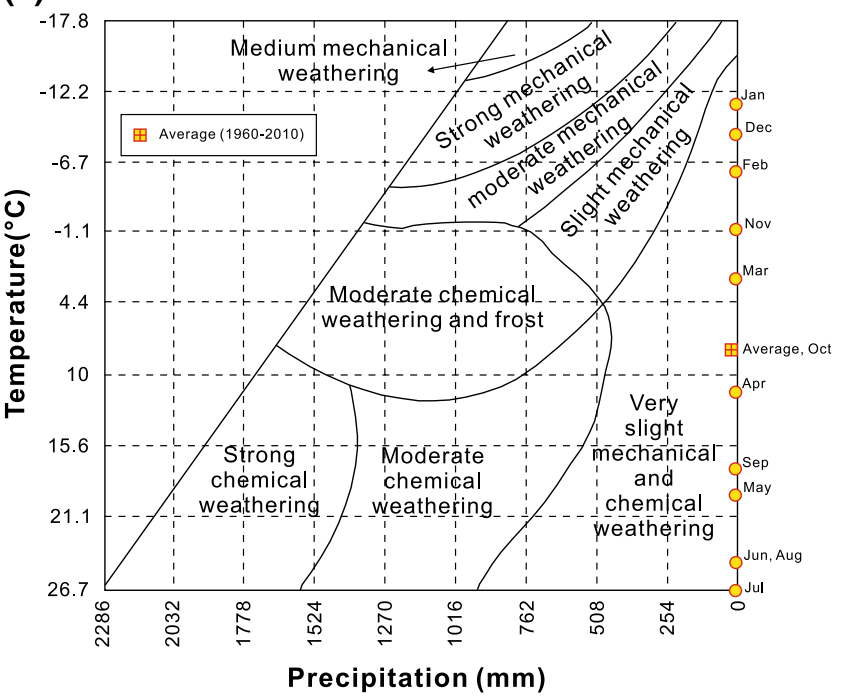

2. The fluvial action is medium or moderate and the chemical weathering and mass movement actions are weak in the Ejina Basin (Figs. 5, 6).

3. The main morphogenetic processes in the Ejina Basin are the desiccation-deflation, aeolian and pluvial erosion processes, while frost action and weathering regimes are weak (Figs. 5, 6).

Applied not only to the characteristic months, such as January in winter month and July in summer month, but also to the "transitional" months, such as April in spring month and October in autumn month, the Peltier diagrams emphasize the annual evolution of the intensity processes, depending on the morphoclimatic conditions. Thus, in each month:

(b)

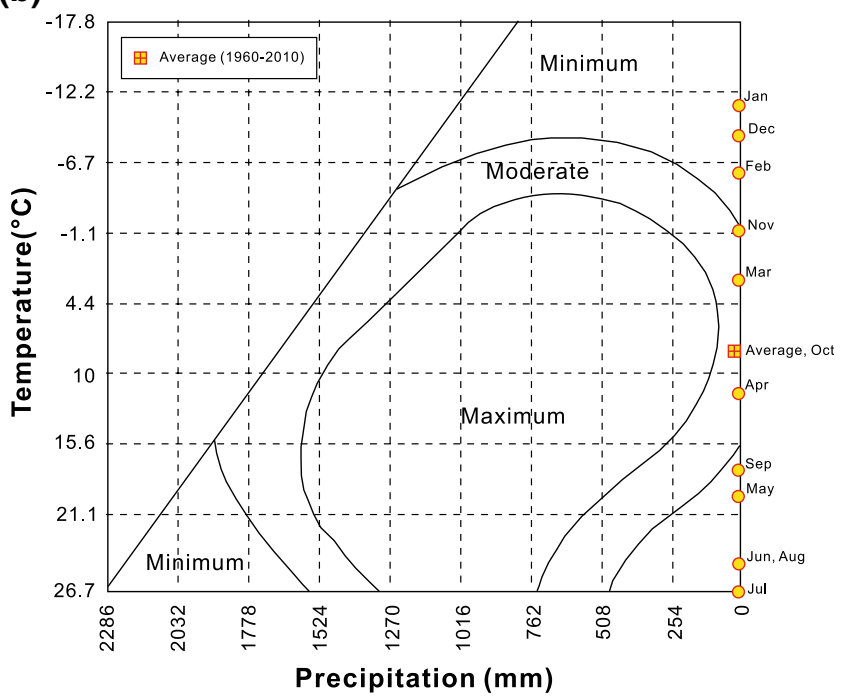

Fig. 6 The affiliation of the characteristic months of the Ejina Basin. a To the morphogenetic regions, $\mathbf{b}$ to the intensity of fluvial action, $\mathbf{c}$ to the type and the intensity of the predominant processes in a Peltier diagram. The base-graphs were after Peltier (1950) 
1. The morphoclimatic conditions define a transitional system between the temperate system and the semiarid system in Jan, Feb, Nov and Dec of winter months, the semiarid system in Mar, Apr and Oct of spring and autumn months, and the aid system in May, Jun, Jul, Aug and Sep of mainly the summer months. (Fig. 6a).

2. The fluvial action is minimum in Jan, Feb, May, Jun, Jul, Aug, Sep and Dec, and moderate in Mar, Apr, Oct and Nov (Fig. 6b).

3. The morphogenetic processes of mechanical and chemical weathering are both minimum in all months (Fig. 6c).

Based on the mathematical correlation between temperature and precipitations, the Pegui diagram classifies the months of the year into five types, i.e., cold and humid, cold and dry, warm and humid, temperate and arid (Pegui 1961). According to this classification, thus, five of the months (mostly winter months) at Ejina Basin, Jan, Feb, Mar, Nov and Dev, are "cold and dry months" (Fig. 7) and this justifies their affiliation to the transitional system between the temperate system and the semiarid system (Fig. 6a). The majority of the months at Ejina Basin, Apr, May, Jun, Jul, Aug, Sep (spring, summer and autumn months) are "arid months" (Fig. 7), which justifies their affiliation to the semiarid and arid system (Fig. 6). Only 1 month at Ejina, October, is a "temperate month", which has the same values of temperature and precipitation to the yearly average values for the studied period from 1960 to 2010 (Fig. 7). However, due to the low precipitation, its morphoclimatic system still belongs to the semiarid system (Fig. 5) (with a dominance of physical processes) and the temperate values of temperature make the chemical alterations somewhat slight in comparison (Fig. 6c).

\section{Discussion}

Subject to the erosive and accumulative action of the geomorphogenetic agents (rivers, glaciers, snow-frost, winds etc.), the Ejina Basin displays morphological responses to climate in accordance with its landform characteristics.

Landform Inconsistency with current climate in the Ejina Basin

In climatic geomorphology, frost weathering (under cold climate) or glaciation, which produces loose rock materials during cold winter, is crucial to the formation of pediment and gorge landforms (Gutierrez 2005; Hoevermann 1985; Mabbutt 1977). Water from rainfall in the humid and warm summer climate transports these materials to lowland and the landform of alluvial fans is consequently developed. Desert plain with gravel pavement on its ground surface can originate via a single or multiple processes. Fundamentally, the processes are produced by water and then aeolian actions and, intrinsically, the landform is modified by differentiation processes (McFadden et al. 1987). The most universally applied process of pavement genesis is deflation, whereby fine particles are exported by the wind, leaving a residue of coarse material that goes on to constitute the pavement.

As illustrated above, the present dominant morphodynamic process under current arid temperate climate in the Ejina Basin should be desiccation-deflation and aeolian processes (Figs. 5, 6). Geomorphologically, formations of landscapes such as desert gorges and pediments are both related with frost weathering processes under cold and wet climate (Hoevermann 1985). Compared with the present suitable morphodynamic process, it implies that a landform inconsistency with current climate exists in the Ejina Basin.

The climatic precondition for the formation of a pediment is a cold winter and an average annual precipitation of 150-300 mm (Hoevermann 1985; Yang 2001). Frost weathering processes in winter and alluvial processes in summer are crucial to the formation of pediment. However, the average annual precipitation and temperature at present day are only about $35 \mathrm{~mm}$ and $8.8^{\circ} \mathrm{C}$ in the Ejina Basin, respectively. The desiccation-denudation processes are predominant over the whole year and the alluvial processes have decreased considerably under present climatic conditions. So an actual formation of pediment cannot take place in the Ejina Basin under present climatic conditions.

Strong erosion processes by water are needed for the formation of desert gorge landscape. The critical amount of annual precipitation for developing desert gorges is thought to be 60-150 $\mathrm{mm}$ (Hoevermann 1985). At present the desert gorge areas are often bare and currently, frost weathering processes are quite weak in the Ejina Basin. Similar to the pediments and alluvial fans, desert gorge formation in the Ejina Basin is now inactive owing to the lack of water. According to Hoevermann (1985), the formation of desert gorge and pediment landscapes, both require much higher precipitation and lower temperature than the current conditions in Ejina Basin (Table 1). Thus, the pediments and desert gorges surrounding the Ejina Basin are relict landforms associated with more humid and colder climate in the past.

Aeolian landforms of small active dunes are closely distributed along the Ejina river banks (Fig. S4). In the sense of climate geomorphology, typical aerodynamic relief often occurs in the area with an average annual precipitation of less than $30 \mathrm{~mm}$ and the dry climate 


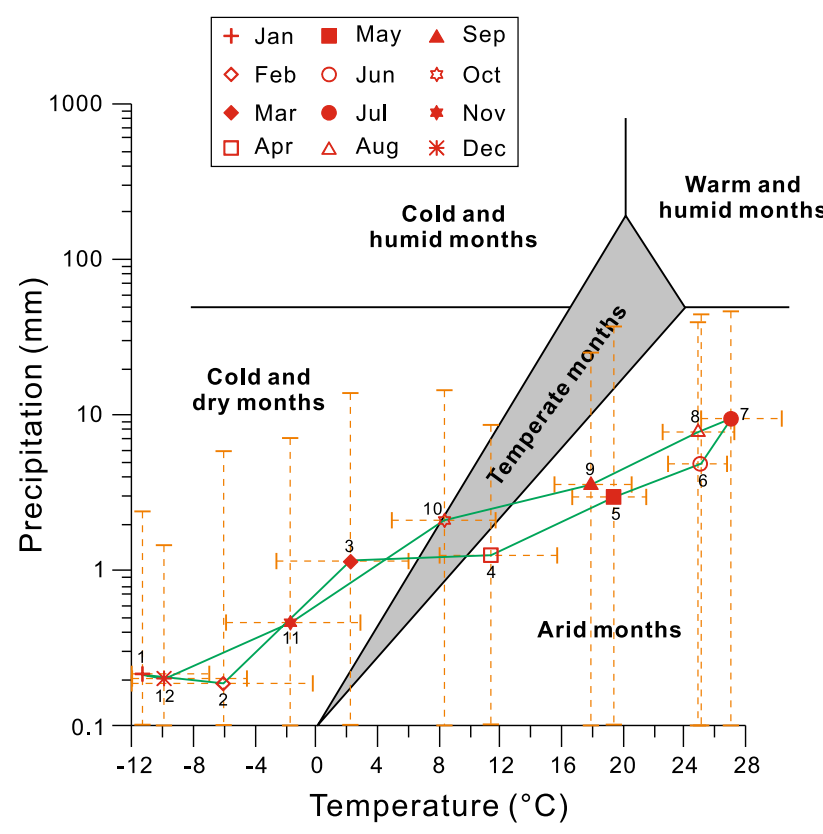

Fig. 7 Pegui climatograms for the meteorological months of the Ejina Basin (the base graph was after Pegui 1961)

promotes the development of shifting dunes, which become stabilized under moister conditions (Hoevermann 1985; Yang et al. 2011a). To some extent, the current annual precipitation in the Ejina Basin $(35 \mathrm{~mm})$ is suitable for the development of aeolian dunes. However, river channels and the nearby areas have somewhat wetter conditions, which are indicated by the relatively high air humidity and the development of grass and shrub vegetation with shallow roots. Therefore, the occurrence of active dunes at short distance and along the river sides represents an abnormal situation. Non-climatic and non-geomorphogenic processes such as the sand source/supply and the effect of sand retention by vegetation, as well as the uneven ground due to shrub vegetation, might be responsible for the formation of aeolian dunes in the Ejina Basin.

Landform instability in the Ejina Basin and its environmental indications

Both field investigations and sedimentary observations, as well as mapping analyses, provide clear evidences that the landscapes in the Ejina Basin and their boundaries have undergone evident changes. For example, the pediment landform around the Ejina Basin is transforming towards desert plains in the lower terrains and towards desert gorges in the higher locations. Many parts of the foot and waist ridge of desert gorges are gradually buried by aeolian sand (Fig. S3d) and an assemblage of gorge and aerodynamic landforms are in the forming. During years with relatively high precipitation amount, vegetation such as desert steppe is well developed on the desert plain (Fig. S1c). The plant communities consist mainly of shrubs and half-shrubs. Therefore, the landscape can be seen as a transitional form between the desert plain and the desert steppe. All these phenomena indicate an unstable situation for landforms in the Ejina Basin under the current climate.

More and more areas of desert plains with gravel pavement are neighbored and occupied by dune fields in the Ejina Basin (Figs. S1d, S5). The occurrence of desert gravel layer is indicative of powerful winds acting on the buried delta/alluvial fans. This indicates that the desert plains are transformed from ancient alluvial fans. Dunes on the surface of desert plains generally possess small geometric patterns, and this further implies that the active dunes developed on an old relief and are young in age. As an aeolian dune is a landform representative of a climate characterized by intensive wind action under a shortage of precipitation, its formation is thus closely related to an increased aridity index (Hoevermann 1985). Such kind of landform shifting, from desert plains to aeolian dunes in ancient alluvial fans, represents a strong indication of regional climatic aridification and land desertification.

The transformation from alluvial fan to desert plain is also evidenced by the widespread thick alluvial strata buried under the Gobi surface (Fig. S2a, b). The ancient alluvial fan in the lower part of the Ejina had extended northward and changed to a lacustrine plain. In terms of climatic geomorphology, desert plain refers to a relief that undergoes a morphodynamic process with balanced wind and water dynamics (Hoevermann 1985). The relief energy on the desert plains is relatively low and the typical amount of average annual precipitation for forming desert plains is 30-60 mm (Table 1). Taking this statement into consideration, one can say that the current climate in Ejina is suitable for the formation of desert plain landform. However, the present-day landform of desert plain is at the early stage of its development, because the outline of a largescale alluvial fan is still recognizable from the remotesensing images (Fig. 2) and on the peripheral edges of the Ejina Basin, our field investigations also confirm that former alluvial landforms like stream channels are still well preserved (Fig. S1a)

Owing to the use of river water and extraction of groundwater for the purpose of irrigation, artificial oases are developed in some areas of the desert plain in the Ejina Basin. The original landscape of desert plain near the banks of the Ejina River have been replaced by an agricultural landscape, which indicates a strong influence of human activities on the regional landscape evolution.

Aeolian dunes were examined in the field. Their height varies greatly at a local scale and ranges from 0.5 to $40 \mathrm{~m}$, with an average $6 \mathrm{~m}$ among 23 individual dunes (Zhu and Yu 2014). However, the dune types do not differ greatly 
from place to place. Compared with the neighboring dune fields in the Badanjilin Desert, where the height of most dunes ranges from 185 to $333 \mathrm{~m}$ and calcareous layers commonly develop on old dune (Yang et al. 2011a), the dunes in Ejina Basin are much lower and calcareous layers are absent, further suggesting that the dunes in Ejina Basin are relatively young. The dunes in Ejina are generally of the single type and are mainly linear or barchan dunes, nebkhas and sand sheets (Fig. S4a, b). Compared with our previous field investigations in other mid-latitude deserts, other dune types such as pyramid or star dunes occur widely in the Taklamakan and the Badanjilin deserts (Yang et al. 2011a; Zhu and Yang 2009; Zhu and Yu 2014; Zhu et al. 2014c). Observations and simulations in the Taklamakan Desert show that some pyramid dunes have been created by erosive processes and in the Badanjilin Desert the multi-directional winds presumably played an important role in the creation of the star dunes (Yang et al. 2004; Zhang et al. 2013). Although seasonal change in the direction of prevailing winds is apparent in the meteorological records from the Ejina weather station (Fig. 3a), there are no balanced wind systems of different directions and the wind energy is weaker than that in the neighboring Badanjilin Desert. This may be a major reason for the lack of development of pyramid and other complicated dunes in the Ejina Basin. In addition, sand source availability can also be a factor.

Generally speaking, the landform instability and geomorphological transformation in the Ejina Basin can be seen as a consequence of the increasing trend towards climatic aridity. Sedimentary profiles with depth of ca 3-4 $\mathrm{m}$ in the central part of the Ejina Basin all consist of the following strata from bottom to top: (a) interbeddings of fine aeolian sand and coarse fluvial deposits; (b) lake sediments; (c) interbeddings of aeolian sands and marsh deposits and (d) interbeddings of aeolian sands and sandy silts (Fig. S2b). This sequence leads to the interpretation that the landform during the earliest period was a desert plain because of the presence of aeolian and fluvial deposits on the lowest part. Thereafter, the climate became less arid and lakes appeared. At a later stage, the process of aridification started and the aeolian process finally replaced the marsh sedimentation. Owing to the insufficient dating data that are currently available, identifying a reliable time scale from these profiles is still challenging. However, the glacial and periglacial sequences in the foot zone of the marginal Alashan highlands provide a comparable chronology. Roughly speaking, the pediments dovetail the glacial-fluvial fans of the last glacial maximum (Hoevermann et al. 1998; Yang 2001). This is a hint that the active formation of pediment took place during the last glacial period. In general, we can say that landforms like pediment and desert gorge indicate higher precipitation in the past and are remnant landscapes in the Ejina Basin, while the landforms like desert plain and aeolian dunes represent that contemporary landforms conform to the present arid climate.

\section{Conclusion}

This paper provides an estimation of the landform distribution and evolution and related environmental indications in the Ejina Basin, northwestern China on the basis of climate geomorphology. Through interpretation of satellite images and field examinations, landforms such as desert plains, pediments, desert gorges, aeolian dunes, fluvial and playa are recognized as the main landforms existing in and around the Ejina Basin. There is strong link between climatic geomorphological processes and landforms, although human activities further heightened its complexity. The contemporary layout and distribution of the landforms in the Ejina Basin are possibly a result of the transformations of the ancient relief during the Late Quaternary Glaciation. Still, elements of an older layout have been preserved. It indicates that the landforms and the boundaries between the different landscapes in the basin are undergoing evident changes or transformations. The average annual precipitation and temperature at present in the Ejina Basin indicate that desert plain and aeolian dunes are contemporary landforms corresponding to the present climate. Relicts of old landforms like pediment and desert gorge are recognized and indicate that the amplitude of precipitation variation in the past has reached $60-200 \mathrm{~mm}$, larger than its present level. These landforms suggest that the regional-scale landscapes in the Ejina Basin are the result of glacial, frost weathering, fluvial and alluvial actions, desiccationdeflation and aeolian processes, as well as climatic changes. Given that some of the natural processes will intensify while others will moderate in the future together with climate change, the evolution phases of morphogenetic processes in the Ejina Basin should be considered with the background of changes of mid-latitude glaciation since the late Pleistocene and Holocene. Sedimentary covers are an important stratigraphic link enabling determination of paleoclimatic conditions and landform evolution. They are not well known in the Ejina Basin; therefore,they should receive more attention in further studies.

Acknowledgments This work was financially supported by the Kezhen Young Talent Project of the IGSNRR-CAS (Grant No.: 2013RC101) and the National Natural Science Foundation of China (Grant Nos.: 41371060 and 41271049). The authors are very grateful to the editor-in-chief James W. LaMoreaux and an anonymous reviewer for their incisive reviews of the manuscript and for their 
valuable comments. Sincere thanks are extended also to Prof. Xiaoping Yang for his generous instructions in the research works of B.Q. Zhu.

\section{References}

Bullard JE, McTainsh GH (2003) Aeolian-fluvial interactions in dryland environments: examples, concepts and Australia case study. Prog Phys Geogr 27:471-501

Derbyshire E, Goudie A (1997) Asia. In: Thomas D (ed) Arid Zone Geomorphology, 2nd edn. Wiley, Chichester, pp 487-506

Fryberger SG, Dean G (1979) Dune forms and wind regime. In: McKee E (ed) A study of global sand seas. United States Geological Survey Professional Paper 1052, Washington, pp 137-169

Garner HF (1959) Stratigraphic-sedimentary significance of contemporary climate and relief in four regions of the Andes Mountains. Geol Soc Am Bull 70:1327-1368

Garner HF (1967) Geomorphic analogs and climax morphogenesis. Ark Acad Sci Proc 21:64-76

Grunert J, Lehmkuhl F, Walther M (2000) Palaeoclimatic evolution of the Uvs Nuur basin and adjacent areas (Western Mongolia). Quatern Int 65-66:171-192

Guo H, Liu H, Wang X, Shao Y, Sun Y (2000) Subsurface old drainage detection and paleoenvironment analysis using spaceborne radar images in Alxa Plateau. Sci China Ser D 43:439-448

Gutierrez M (2005) Climatic geomorphology. Elsevier, Amsterdam

Hoevermann J (1985) Das System der klimatischen Geomorphologie auf landschaftskundlicher Grundlage. Zeitschrift fur Geomorphologie Neue Folge 56 (Supplementary Band):143-153

Hoevermann J, Hoevermann E, Lehmkuhl F (1998) Geomorphologische Untersuchungen im noerdlichen Vorland des Qilian Shan, China. Berliner geographische Abhandlungen 63:83-98

Kalvoda J (2012a) Integration of orogenetic and climate-morphogenetic processes during the landform evolution of the High Asian Mountains in the Quaternary. Quatern Int 279-280:233

Kalvoda J (2012b) Dynamics of Quaternary Landform evolution in high and central Asia recorded by gravitational signatures of the EGM 2008. Quatern Int 279-280:233

King LC (1953) Canons of landscape evolution. Bull Geol Soc Am 64:721-762

Lehmkuhl F, Haselein F (2000) Quaternary paleoenvironmental change on the Tibetan Plateau and adjacent areas (Western China and Western Mongolia). Quatern Int 65-66:121-145

Lv Y, Gu Z, Ala A, Zhang H, Goran P, Lei G (2010) ${ }^{10}$ Be in quartz gravel from the Gobi Desert and evolutionary history of alluvial sedimentation in the Ejina Basin, Inner Mongolia, China. Chin Sci Bull 55:3802-3809

Mabbutt JA (1977) Desert Landforms. The MIT Press, Cambridge MA

McFadden LD, Wells SG, Jercinovich MJ (1987) Influences of eolian and pedogenic processes on the origin and evolution of desert pavements. Geology 15:504-508

Nikiforov SL, Pavlidis YA, Rachold C, Grigoryev MN, Rivkin FM, Ivanova NV, Koreisha MM (2005) Morphogenetic classification of the Arctic coastal zone. Geo-Mar Lett 25:9-97

Panizza M (2009) The geomorphodiversity of the Dolomites (Italy): a key of geoheritage assessment. Geoheritage 1:33-42

Parsons AJ, Abrahams AD (2009) Geomorphology of desert environment, 2nd edn. Springer, Berlin

Pegui CP (1961) Précis de climatologie. Paris

Pekala K (1975) Contemporary morphogenetic processes in Sant Valley. Bulletin de l'Académie Polonaise des Sciences-Série des Sciences de la Terre 23:221
Pekala K (1980) Morphogenetic processes and cover deposits of nunataks in the Hornsund area (SW Spitsbergen). Polish Polar Research 1(2-3):9-44

Pekala K, Zietara T (1977) Concerning yearly and monthly balance of recent morphogenetic processes in Sant Valley. Bulletin de l'Académie Polonaise des Sciences-Série des Sciences de la Terre 25:149

Pekala K, Zietara T (1980) The role of present-day geomorphological processes in the shaping of the relief of the Sugnugurin-Gol river basin (Mongolia). Bulletin de l'Académie Polonaise des Sciences-Série des Sciences de la Terre 28:115

Peltier LC (1950) The geographic cycle in periglacial regions as it is related to climatic geomorphology. Ann Assoc Am Geogr 40:214-236

Pope GA, Dorn RI, Dixon JC (1995) A new conceptual model for understanding geographical variations in weathering. Ann Assoc Am Geogr 85:38-64

Robustelli G, Ermolli ER, Petrosino P, Jicha B, Sardella R, Donato P (2014) Tectonic and climatic control on geomorphological and sedimentary evolution of the Mercure basin, southern Apennines, Italy. Geomorphology 214:423-435

Stevens T, Carter A, Watson TP, Vermeesch P, Ando S, Bird AF, Lu H, Garzanti E, Cottam MA, Sevastjanova I (2013) Genetic linkage between the Yellow River, the $\mathrm{Mu}$ Us desert and the Chinese Loess Plateau. Quatern Sci Rev 78:355-368

Stoddart DR (1969) Climatic geomorphology: review and re-assessment. Prog Phys Geogr 1:159-222

Sun JM (2002) Provenance of loess material and formation of loess deposits on the Chinese loess plateau. Earth Planet Sci Lett 203:845-859

Testa B, Aldighieri B, Bertini A, Blendinger W, Caielli G, de Franco R, Giordano D, Kustatscher E (2013) Geomorphodiversity of the San Lucano Valley (Belluno Dolomites, Italy): a well-preserved heritage. Geoheritage 5:151-172

Tricart J, Cailleux A (1969) Introduction à la Géomorphologie Climatique. Le Modéle des Régions Séches, Paris

Wilson L (1968) Morphogenetic classification. In: Fairbridge RW (ed) The encyclopedia of geomorphology. Dowden, Hutchinson and Ross, Stroudsburg, pp 717-729

Yang X (2001) Late Quaternary evolution and paleoclimates, western Alashan Plateau, Inner Mongolia, China. Zeitschrift fur Geomorphologie Neue Folge 45:1-16

Yang S, Ding Z (2008) Advance-retreat history of the East-Asian summer monsoon rainfall belt over northern China during the last two glacial-interglacial cycles. Earth and Planetary Science Letters 274:499-510

Yang X, Scuderi LA (2010) Hydrological and climatic changes in deserts of China since the late Pleistocene. Quatern Res 73:1-9

Yang X, Rost KT, Lehmkuhl F, Zhu Z, Dodson J (2004) The evolution of dry lands in northern China and in the Republic of Mongolia since the last glacial maximum. Quatern Int 118-119:69-85

Yang X, Scuderi L, Liu T, Paillou P, Li H, Dong J, Zhu B, Jiang W, Jochems A, Weissmann G (2011a) Formation of the highest sand dunes on Earth. Geomorphology 135:108-116

Yang X, Scuderi L, Paillou P, Liu Z, Li H, Ren X (2011b) Quaternary environmental changes in the drylands of China-a critical review. Quatern Sci Rev 30:3219-3233

Yang X, Li H, Conacher A (2012) Large-scale controls on the development of sand seas in northern China. Quatern Int 250:74-83

Zhang D, Narteau C, Rozier O, du Pont SC (2013) Morphology and dynamics of star dunes from numerical modeling. Nat Geosci 5:463-467

Zhu B, Yang X (2009) Chemical weathering of detrital sediments in the Taklamakan Desert, northwestern China. Geogr Res 47:57-70 
Zhu B, Yu J (2014) Aeolian sorting processes in the Ejina desert basin (China) and their response to depositional environment. Aeolian Res 12:111-120

Zhu B, Yang X, Liu Z, Rioual P, Li C, Xiong H (2012) Geochemical compositions of soluble salts in aeolian sands from the Taklamakan and Badanjilin deserts in northern China, and their influencing factors and environmental implications. Environ Earth Sci 66:337-353

Zhu B, Yu J, Qin X, Rioual P, Liu Z, Xiong H (2014a) Formation and evolution of sand deserts in Xinjiang, NW China: I. provenances of desert sands. J Geog Sci 24:177-190
Zhu B, Yu J, Qin X, Rioual P, Zhang Y, Xiong H (2014b) Formation and evolution of sand deserts in Xinjiang, NW China: II. the palaeo-environmental reconstruction. J Geog Sci 24:539-559

Zhu B, Yu J, Rioual P, Ren X (2014c) Particle size variation of aeolian dune deposits in the lower reaches of the Heihe River basin, China. Sed Geol 301:54-69 